Aleksandra GASZTOLD

DOI : $10.14746 /$ pp.2017.22.3.13

University of Warsaw

\title{
A feminist approach to security studies
}

\begin{abstract}
The main goal of this article is to present problems related to using a feminist approach in security studies. The starting point are some of the basic terms used in the internally diverse sphere of feminist theory and their application in the field of political science. An attempt is also made to define the objectives of selected feminist studies that can be used in the analysis of domestic and international security issues. The main thesis of the article is the assertion that security studies are dominated by assigned gender stereotypes and meanings embedded in the so-called male gaze.
\end{abstract}

Key words: feminism, gender, sex, security, security studies, political science

\section{Introduction}

A $\mathrm{s}$ an academic theory, what makes feminism stand out is, above all, the subject of study: women and their roles in society, politics and international relations. This theory assumes that there is a distinction between women's subjective traits and their behaviour in society. Feminism focuses on their fortunes and place in the world while, at the same time, discussing these questions in relation to men and masculine and patriarchal relationships. Hence, the key terms in this view will be the notions of sex and gender and their impact on one's social position. On the academic side, feminism is included in the post-positive movement because of its critique of, and opposition to, the dominant gender hierarchy and so-called male gaze. It should be noted that feminism is not a monolith; various streams of feminism can be discerned that are usually called waves. Some authors use the term in the plural, i.e., feminist theories. However, the starting point for discussions by individual authors is an assumption about the social construct of gender and its role and place both for political science theory for public life.

When encountered in analyses of the role and importance of women in the context of political violence, the above-mentioned male gaze centralises processes of representation in which the male point of view (predominantly heterosexual) is privileged. This approach exhibits an unequal distribution of rights and the objectification of women (and other genders). It has an influence (usually varied or inverse) on both the person observed and on the observer (Stump, Dixit, 2013, p. 58). In this view, we can observe an emphasis on women as objects, who are forced to act by certain determinants, such as race, social norms, religion, "feelings of hopelessness," to act in a "typically" male way in the sphere of security. It does not perceive women as human beings who are responsible for themselves or who are capable of making their own independent decisions or determining their own path in life. This is often because it is men who tell us about these women, denying them their own voice (his story instead of her story). Notions of harm and suffering are emphasised while at the same time denying the deliberate choice of specific actions in the political or public sphere (Wibben, 2011). 
Feminism, like other post-positivist concepts, assumes the crossing of boundaries and thus a critique of positivist achievements and the deconstruction of the theory on account of variable gender. Feminists are mainly women, but more and more men are working as researchers in this field all the time. This is related to a common phenomenon in political science whereby men are allocated places as actors and as active participants in politics. Christine Sylvester highlights this in her analysis of the theory of international relations. According to her, women serve only a supporting role for men's policies, and so they occupy other positions from which they may "dabble in" international relations (Sylvester, 1994, p. 4). Sylvester further highlights the fact that men are directly identified with states and the policies states implement. This is reflected, inter alia, in the presentation of their role in society, which is more powerful than that of women, as policymakers, politicians, soldiers, terrorists, etc. In this way, they are forced - with the help of the outlined theories - into particular positions, and they take action (perform roles) in accordance with the premise accepted by the researcher. This premise may, however, be misleading (and thus theorising) or reflect the innate talents of the person being analysed. The assignment of specific traits and values does not necessarily have to become reality (Sylvester, 1994, p. 5).

\section{Variable gender}

The key concept that binds together the various interpretations of feminism is that of gender, a phenomenon that permeates all spheres of social life and is therefore applied in academic discussions of them. This term indicates an interdisciplinary approach, as it relates to many spheres of social life and several academic disciplines. According to feminists, a negation of cultural gender can be observed in traditional research. This therefore undermines any attempt at gender-neutral analysis, where the focus is on human beings and their interactions in public space. They acknowledge that existing academic paradigms distort reality by creating an illusory myth of objectivity without taking into account the conditions that influence the role and position of political actors. The polarisation of characteristics attributed to women and men is constantly being created and reproduced by means of roles, standards for acceptable behaviour, social norms and stereotypes attributed to that which is male and that which is female. "Nature determines whether we are male or female; culture decides what it means to be male or female" (Merz, 1979, p. 9).

The difference between a man and a woman is natural since it is the result of inherent physical traits and does not lead to the development of moral, political or social norms, as it is not relational. It is given meaning only when it is interpreted by the cultural context. Thus, the gender division is a duality: it is, at the same time, natural and cultural, real and symbolic, biological and psychological (Agacinski, 2000, p. 25). Sex determines - particularly in patriarchal systems - the biology (nature) and destiny of both women and men. The publication that showed that gender is a cultural, rather than innate, construct was Robert J. Stoller's 1968 monograph (Stoller, 1968). This research began being used to demonstrate that a woman's life is not determined by her sex. Gender, on the other hand, opened up new possibilities, although it was relational. However, 
this is the term that the majority of feminists started to use. The term gender is not, however, the only one used by feminists, nor does it lack ambiguity. Judith Butler, who came up with the concept of gender performativity, voiced her categorical disagreement with the treatment of feminist thought only through the prism of cultural gender. She expressed doubts about exposing the distinction between the concepts of sex and gender. In her opinion, the blurred boundaries between what is biological and what is social do not interfere with the study of the entirety of issues involved in the female question. Biological sex can determine an individual's identity, but it is culturally determined gender that has historically determined - through constant repetition and performance - behaviour and means of self-expression. Defining cultural and social gender by referring to biological sex (which is not neutral) validates and reproduces gender differences (doing gender). It then becomes a fact around which particular social relationships, inequalities and discrimination develop. The question of sexual difference, in Butler's view, is and will continue to be questioned and will remain an open question. Since this difference is an impermanent category created by discourse, he therefore proposes that it be replaced with differentiation (Butler, 2005).

Every culture expresses through language that which is conferred upon the individual sexes. This also includes expectations about how each person should behave. Exaggerated expectations are established as gender stereotypes that may be related to particular traits associated with sex (Basow, 1992). Through their generalisation and the so-called male gaze, sweeping generalisations related to the articulation of political needs and interests usually do not introduce gender differentiation or the actual position of the individual within society. They focus on the person-citizen-man. Therefore, proponents of the feminist perspective also point out that, at least within political science, avoidance of the gender aspect excludes from research certain determinants and processes that are essential to the world of politics (True, 1996, pp. 211-212) Assuming that gender is a social construct related to the assignment of roles and norms, it is also related to the identity of the individual, their social identity and way of life. That is to say it has an impact on the distribution of power, privilege and prestige. The system of gender roles and their inter-relationships conditions every aspect of human life, including security and political violence (Alison, 2004).

The theory of feminism, like other academic theories, uses categories and terms that are specific to it. Joanna Bator recognises as essential "interpretative categories of every feminist theory: sexual differences, women and emancipation." On the other hand, she considers to be characteristic traits "perspectivism, intersexuality, the relationship between knowledge/power and sexual differences, strategic thinking, the relationship between theory and practice, the emphasis on what in the 'male' tradition was usually overlooked as casual, private, corporal, feminine" (Bator, 2001, p. 44). The common denominator among the various feminist factions is the conviction that women, because of their sex, are abused (oppressed) by the system and that this situation can and must be changed. And that women should be the driving force. Hence, ideology is very often translated into action, including involvement in social, political, artistic or theoretical and research activities aimed at "a transformation of knowledge" (Ślęczka, 1999, p. 12). The main levels of "women's oppression within the system of knowledge" that need to be opposed are sexism, patriarchy and phallogocentrism (Grosz, 1988, p. 93). 


\section{Goals of feminist research}

In the initial phase, the purpose of feminist research was to show the universally recognised as true and normal androcentric tendency that was unequivocally influencing theoretical models in the field of political science. They were in large part based on the conviction that gender neutrality existed and therefore if, for example, the problem of a rational decision maker were analysed, a model would developed that was based on traits attributed to men. In classic publications on decision-making in foreign policy, although a great deal of attention was devoted to the personality traits of the decision maker, no distinction was made between whether it was a man or a woman (Verba, 1961; Lentner, 1974; Janis, 1989).

Another goal of feminism was to re-establish the presence of women in many areas of social life, including security studies. The intention was to analyse women as actors and their experiences while assuming that the latter differ from men's experiences, since the social determinants may differ in view of the gender roles mentioned above and the meanings assigned to them. This stage in the development of feminism was called "adding women." The priority was to include women as objects of analysis and gender as a variable concept. However, the various attempts undertaken in this area did not have a significant impact on traditional models, research methods or techniques, or the conceptual grid of political science, at least in Poland., Language that fully emphasises the presence of women in social and political life is significant for the development of feminist thought. It is of particular value in the widespread cultural underrepresentation of women. Judith Butler calls for even more intense work on language that would seem to be "necessary to foster the political visibility of women" (Butler, 2005, p. 145). Contemporary studies focus on challenging existing theoretical and methodological assumptions, in particular pointing out inconsistencies in language and terminology, which puts women in a lower/worse position than men. This is primarily due to the placement of women in a specific context (Peterson, 1992, pp. 191-197).

The basic goal of research within the heterogeneous feminist movement is the creation of a theory based on the experiences and using the language of women and to ask questions previously ignored. In doing so, the emotional involvement of the researcher is permitted, in contrast to the artificiality of male objectivity and distance. In this conception, the research process is intended to shape the consciousness of both the object of the research and the researcher. They are meant to reflect practical knowledge, which, among other things, is conditioned by their experiences in everyday life (Harding, 1987). Maria Mies suggests, for example, that research should take into account: (1) conscious sympathy; (2) women's experiences (bottom-up studies); (3) practical features and solutions (awareness-raising features) (Mies, 1983). Hence, qualitative research is favoured, especially participant observation and analysis of experiences and case studies (Reinharz, 1979). In this view, the researcher may play the role not of an expert, but of a person who is learning and is therefore open to the results and to changing their initial assumptions. It is essential to use various kinds of research methods and techniques and to properly analyse the collected material with the aim of expanding knowledge about the role of women, but also about the specifics of what is masculine and what is feminine and therefore about cultural and social tensions related to gender. The source's 
"sex" should also be verified as a decisive factor in the narrative that is in a certain way "contaminated" by a particular perspective (the so-called male gaze). Men may have a tendency to imbue their work about women or dedicated to women with their view of women, thereby distorting reality. Cythia Enloe suggests using a gender impact analysis in research concerning (local and global) political processes. In order for this method to be effective, it should take into account the situation both before a decision is made and after. This will allow the researcher to answer questions about how political decisions influence men and women; whether it is possible to distinguish within these groups certain sets of people who will feel the impact of a policy more strongly (specific individuals, occupations, age ranges, etc.) and whether that political action will have an impact on the relationship between men and women, e.g., by limiting or aggravating inequalities. "To make sense of today's complex world, we need to understand that many decisions have not only gendered consequences but gendered causes - that is, causes flowing form presumptions or fears about femininity or masculinity" (Enloe, 2007, p. 17).

\section{Challenges in security analysis}

As generally understood, the subject of Security Studies covers contemporary international relations (e.g., in the United States), combined with national and international security, as well as peace research. These areas have had relatively few points in common with feminism due to the high degree of scepticism among researchers about everything that is postmodern in security analysis (Walt, 1991, p. 223). Following Jacek Czaputowicz, three streams of feminism can be discerned in international relations. The first, empirical stream focused on determining the activities of women in various fields of international relations. The second, feminist standpoint called for the creation of a feminist epistemology and the inclusion of women's perspectives in the study of international relations. On the other hand, the third, postmodernist stream recognised that "women are a category thought up in order to maintain relationships of inequality, domination and subordination that have become recognised as natural" (Czaputowicz, 2007, p. 377). In particular, the question of the peaceful nature of women raised by female feminist researchers and debates about the sources of pacifism stemming from nature or culture have found a place in studies on war and peace, especially in the criticism of male militarism (Jones, 1996).

Militarism is seen as one form of patriarchal social and structural violence. This perspective predestines women (and children) to passive participation in armed combat. This view rules out both an active role for women in military conflict (combatants) and for men as non-participants (non-combatants) (Peach, 1993, pp. 84-96). Those actors who are able to take part in debates about national security are also expected to be possessed of a rationality that is associated with male traits. Women, because of their life-giving power, which is associated with nature, emanate emotionality or "softness". It has therefore become accepted, particularly in countries where the perception of national security is based on militarised solutions, that the admission of women to discussions on or shaping security requires their defeminisation. In other words, that they be de facto stripped of their femininity. Enloe calls this phenomenon muscular 
thinking (Enloe, 2007, p. 40). The impact of feminism on analyses of armed conflict is primarily related to the introduction of the role of the gender factor in the formation of militarism. Thus, it was suggested that our understanding of peace be broadened because of the importance of gender in shaping social relations. Attention was thus paid to the cultural and social conditions that are the source of militarism and consequently of wars. Feminism has enriched traditional studies of armed conflicts by including problems that arise from social relations, particularly the performance of certain gender roles. The integrative function of the practical side of feminism has for years been reflected in the efforts made by women's organisations aimed at peace education and the development of alternative visions of social structures in regions affected by crises (Burguieres, 1990).

The broadening of our understanding of security, as noted by J. Ann Tickner, to include economic and environmental aspects has caused the state to cease being a suitable (and self-sufficient) institution for guaranteeing security. On the other hand, the basic goal of feminism in security studies is to introduce the category of gender as a constant variable that conditions reality and to improve our knowledge of women's experiences. This is based on the conviction that by exposing unequal gender relations and looking at them from a woman's point of view, it is possible to establish the sort of comprehensive definition of security that modern critical thinking has been aspiring to come up with. Due to our traditional understanding of the internal and external functions of the state in the area of ensuring security primarily from a military point of view - forever associated with masculinity - the roles of women have been marginalised and even omitted (Tickner, 1997, pp. 187-190).

Violence is an intrinsic part of security considerations. Violence against women, especially sexual violence, cannot in any way be compared to the experience of this sort of violence against men. Violence against women is believed to be greater in militarised societies and endorsed in patriarchal systems (e.g., through legislation, controlling women's right to their own body or image and other customary practices). The main institution perpetuating this state of affairs and reflecting society on a micro-scale is the family. "As co-operation between the family and the larger society is essential, else both would fall apart, the fate of three patriarchal institutions, the family, the society, and the state are interrelated" (Millett, 2005, p. 42). In addition, male supremacy is not based on physical strength, but rather on the acceptance of a certain system of values. A significant role is played by socialisation and universally accepted prejudices about the supremacy of men, which perpetuate their superior position. Kate Millett emphasises that patriarchal communities generally have a tendency to combine cruelty with sexuality as an expression not so much of evil but of power. Where sadism is associated with "the masculine role" and the experience of being a victim with "the feminine role" (Millett, 2005, p. 48). These same observations have emerged in psychoanalysis and studies on pornography. Sex, in Millett's view, is a status that has political implications in that in comes down to a relationship of domination and subordination and meets Max Weber's definition of control (Herrschaft) (Millett, 2005, p. 38).

Anti-war feminists recognise that war is a male world in which there is no room for women. This conviction is based on the premise that women possess an internal moral voice that differs completely from that of men and that calls for peaceful coexistence. 
This is primarily related to caring, tenderness, the need to build relationships and take responsibility for others. On the other hand, the male view favours justice, rights and independence (ethics of justice). The concept of ethics of care first appeared in the 1980s on the basis of maternal feminism, and its main premise is that so-called maternal practices can transform socio-political systems to eliminate wars (Ruddick, 1989). The morality of women, based, first and foremost, on preserving their offspring (an emotional bond and duty), precludes the use of military means because they are lifethreatening. In this view, the mother-child relationship is transferred to social relationships in general. And traits like masculine aggression and the desire for domination, culminating in armed struggle, are condemned. Nevertheless, this approach strengthens the traditional perception of women and men. Women are associated with nature (and the private sphere), and thus with peace, while men are associated with culture (and the public sphere), and thus with war. Although, before the Enlightenment, traits like wildness and a lack of restraint were attributed to nature, alongside aspects like giving life and caring, modernity has made an attempt to understand (to study) nature, and thus to tame it, which has meant nothing other than subjugation to men. Accordingly, nature was and is treated as a lower order of existence, while culture, with its ability to transform ("socializing" and "transforming" nature) is something different and superior ${ }^{1}$ (Ornter, 1974, p. 73). Sara Ruddick has discerned three attitudes that can be observed in women in the context of discussions on war: the suffering mother, the outsider and the peacemaker. These can overlap or even collide with one another. They reflect the stereotypical understanding of these concepts. Thus, the first one is related to the image of the suffering mother, the bond keeping the family together, who also has the potential to reconstruct the social structure in the wake of armed conflict. This is the most deeply rooted image of women in relation to war. The second attitude assumes the alienation - by force or by choice - of women in relation to war because of the male nature of war. War is perceived as a form of fanatical misogyny that fosters and rewards behaviour related to violence against women. The last attitude is about the ability to build relationships and ways to resolve conflict without resorting to violence. In this view, war is an inherent part of culture. Ruddick suggests using the term war culture. On the other hand, opposition to this phenomenon should focus on the introduction of social changes and different ways of thinking based on the premise that women have the capacity to build relations peacefully (Ruddick, 1998). Radical political feminism based on maternal thinking and caring has been criticised for not taking into account the perspective of civic feminism. It is unable to explain, for example, the high level of support among women for military actions conducted by their own country. This was noted by Jean Bethke Elshtain, who denies the existence of a distinct, peaceful "nature" among women. On the other hand, she does not rule out the performance, during wartime, of culturally established roles concerning the social construction of men as "just warriors" and of women as "beautiful souls" (Elshtain, 1989).

Sex is an essential element of research on political violence, including terrorism (Zięba, 2016). Jacob L. Stump and Priya Dixit recognise that feminist concepts are ap-

1 "Thus culture (ie every culture) at some level of awareness asserts itself to be not only distinct from but superior to nature, and that sense of distinctiveness and superiority rests precisely on the ability to transform - to 'socialize' and 'culturalize' - nature." 
plied in research on terrorism (Stump, Dixit, 2013, p. 58). Researchers emphasise, first of all, the role of patriarchal systems in encouraging and sometimes forcing women to take part in terrorist organisations and terrorist acts. A patriarchy can be understood as a structure based on certain convictions about how people should behave and the values attributed to these behaviours. According to Cynthia Enloe, one can discern, from among these, the conviction that women and men are different. This difference is "intrinsic and unalterable" and predestines everyone to specific social roles. According to this view, men are naturally qualified to be breadwinners, to ensure security and to take part in public life, etc. as a result of their traits: increased rationality, sex drive and physical strength. On the other hand, women fulfil their destiny in the private sphere, where they are grateful to, and dependent on, men. In such systems, it is possible to note the following: first, the privilege of masculinity and, second, the marginalisation of women and that which is feminine. These two essential features of the system are legitimised by being perpetuated in views and in daily practice, thus becoming tradition (Enloe, 2007, pp. 67-68). Research does not, however, support the notion that the mechanism of coercion is a decisive factor for participation in terrorist activities. The social environment may play an important role in involving women in terrorism, but the decisive factor may equally be earlier involvement in political life (Jacques, Taylor, 2013).

The patriarchal view may be associated with the male gaze, which objectifies women, robbing them of their own narratives about themselves. Feelings of harm and suffering are often emphasised, thus denying them their own rational choices (Shepherd, 2010; Tickner, 1997). A perfect example can be seen in attempts to explain the martyrology of women, including sacrificing their own lives (e.g., by taking part in suicide attacks). These are often presented as acts of desperation; they are relativised and treated with compassion.

The involvement of women in terrorism or other forms of armed struggle can also be seen through the prism of emancipation and understood as a break with the established (patriarchal) order and as masculinisation. The empowerment and emancipation of women to take part in terrorism or guerrilla warfare is seen as a revolutionary trend in breaking with their earlier, often inhuman treatment. The neutral form seems to be showing the involvement of women in political violence through the lens of an equal right to political expression, even if this takes on the extreme form of equal access to suicide bombings. On the other hand, the application of the view of transversal politics (Yuval-Davis, 1994) in studies on terrorism emphasises the diversification of roles played by women in terrorist organisations. Differences in individual functions and tasks are related not with one's sex within an organization, but in the specific nature of the organisation and in interaction within the group. Another approach, called intersectionality, is presented by researchers included in so-called postcolonial feminism (Yuval-Davis, 1997). In this field, efforts are being made to show cause-and-effect relationships between racism and political, economic and cultural colonialism, and the involvement of non-white (nonWestern) women in political violence in the postcolonial world (Chowdhry, Nair, 2002). This approach therefore emphasises the role of internal and external conditions as well as racial and ethnic differences that have an impact on the type of actions undertaken and involvement in terrorism and other forms of armed conflict. 


\section{Conclusions}

Despite the diverse range of attitudes and movements, the goal of feminist works seems to be: (1) a critical analysis of traditional theories and concepts, paradigms and language; (2) the creation of a feminist conceptual grid, premises and explanations that are useful for both theory and practice (Light, Halliday, 1994, p. 51). Feminism recognises that traditional theories of political science marginalise the importance of women, as well as the role of gender as a category in social and political life. The main goal of feminism is to raise awareness and thereby to try to universalise this approach in both theory and in practice (Hartsock, 1979). This also marginalises the role of quantitative research, which is perceived as a patriarchal tool that encloses science within the confines of the male vision. Feminism sees itself as a new body of knowledge about existing problems. In this view, an analysis of the involvement of women in the security sphere, particularly in relation to political violence, does not serve to set women against men, but to broaden our knowledge of human nature and of political activity in general (Wesley, 2006). Supporters of the feminist perspective have noted that the gender aspect is crucial to the study of certain determinants and political processes and of security issues as a whole. Gender is a social construct, and it therefore creates and impacts not only the individual but also all of society. Feminist theory can be used to analyse various security phenomena, including armed conflict, terrorism and other actions related to political violence because it focuses on research at the level of the individual, both men and women. The importance of gender differences as a variable that makes up social reality is essential in our understanding of political behaviour and in security studies. It allows us to broaden the scope of analysis and to show that particular phenomena (including nonmilitary threats) have broad cultural and social and even biological determinants that shape their genesis, structure, functioning and have an impact on the consequences. The feminist approach enables a more complete analysis of women's motives in undertaking political activity and in how they go about it, and thus makes it possible to demonstrate the specificity of security-related behaviour.

\section{Bibliography}

Agaciński S. (2000), Polityka ptci, thum. M. Falski, Wydawnictwo KR, Warszawa.

Alison M. (2004), Women as Agents of Political Violence: Gendering Security, "Security Dialogue", vol. 35 , no. 4 .

Basow S. A. (1992), Gender Stereotypes and Roles, Books/Cole, Pacific Grove.

Bator J. (2001), Feminizm, postmodernizm, psychoanaliza. Filozoficzne dylematy feministek drugiej fali, Słowo/obraz terytoria, Gdańsk.

Burguieres M. K. (1990), Feminist Approaches to Peace: Another Step for Peace Studies, "Millennium: Journal of International Studies", vol. 19, no. 1.

Butler J. (2005), Subjects of Sex/Gender/Desire, in: Feminist Theory: A Philosophical Anthology, eds. A. E. Cudd, R. O. Andereasen, Blackwell Publishing, Malden MA.

Chowdhry G., Nair S. (2002), Power, Postcolonialism and International Relations. Reading Race, Gender and Class, Routledge, London-New York.

Czaputowicz J. (2007), Teorie stosunków międzynarodowych. Krytyka i systematyzacja, Wydawnictwo Naukowe PWN, Warszawa. 
Elshtain J. B. (1987), Women and War, Basic Books, New York.

Enloe C. (2007), Globalization \& Militarism: Feminists Make the Link, Rownam \& Littlefield Publishers, Lanham-Boulder-New York-Toronto-Plymouth.

Grosz E. A. (1988), The In(ter)vention of Feminist Knowledges, in: Crossing Boundaries: Feminism and the Critique of Knowledges, eds. B. Caine, E. A. Grosz, M. de Lepervanche, Allen and Unwin, Sydney.

Harding S. (1987), Introduction: Is There a Feminist Method?, in: Feminism \& Methodology: Social Science Issues, ed. S. Harding, Indiana University Press, Bloomington-Indianapolis.

Hartsock N. (1979), Feminist Theory and the Development of Revolutionary Strategy, in: Capitalist Patriarchy and the Case for Socialist Feminism, ed. Z. R. Eisenstein, Monthly Press Review, New York.

Jacques K., Taylor P. J. (2013), Myths and Realities of Female-perpetrated Terrorism, "Law and Human Behavior", vol. 37.

Janis I. L. (1989), Crucial Decisions. Leadership in Policymaking and Crisis Management, The Free Press, New York.

Jones A. (1996), Does the 'Gender' Make the World Go Round? Feminist Critiques of International Relations, "Review of International Studies", vol. 22, no. 4.

Lentner H. H. (1974), Foreign Policy Analysis: A Comparative and Conceptual Approach, Charles E. Merrill Publishing Company, Columbus.

Light M., Halliday F. (1994), Gender and International Relations, in: Contemporary International Relations: A Guide to Theory, eds. A. J. R. Groom, M. Light, Pinter Publishers, London.

Merz F. (1979), Geschlechterunterschiede und ihre Entwicklung, Ergebnisse und Theorien der Psychologie, Verlag für Psychologie, Göttingen.

Mies M. (1983), Towards a Methodology for Feminist Research, in: Theories of Women's Studies, eds. G. Bowles, R. D. Klein, Routledge and Kegan Paul, London.

Millett K. (2005), Theory of Sexual Politics, in: Feminist Theory: A Philosophical Anthology, eds. A. E. Cudd, R. O. Andereasen Blackwell Publishing, Malden MA.

Ortner S. B. (1974), Is female to male as "nature" to "culture", in: Women, Culture and Society, eds. M. Z. Rosaldo, L. Lamphere, Standford University Press, Standford.

Peach L. J. (1993), Women at War: The Ethics of Women in Combat, Indiana University Press, Bloomington.

Peterson V. S. (1992), Transgressing Boundaries: Theories of Knowledge, Gender and International Relations, "Millennium: Journal of International Studies", vol. 21, no. 2.

Reinharz S. (1979), On Becoming a Social Scientist: From Survery Research ad Participant Observation to Experimental Analysis, Jossey-Bass, San Francisco.

Ruddick S. (1989), Maternal Thinking Toward a Politics of Peace, Ballantine Books, New York.

Ruddick S. (1998), 'Woman of Peace'. A Feminist Construction, in: The Women and War Reader, eds. L. A. Lorentzen, J. Turpin, New York University Press, New York.

Shepherd L. J. (2010), Feminist Security Studies, in: The International Studies Encyclopedia, ed. R. A. Denemark, Blackwell Publishing, Oxford.

Stoller R. J. (1968), Sex \& Gender: On The Development of Masculinity and Feminity, Science House, New York.

Stump J. L., Dixit P. (2013), Critical Terrorism Studies: An introduction to research methods, Routledge, London-New York.

Sylvester Ch. (1994), Feminist Theory and International Relations in the Post-Modern Era, Cambridge University Press, Cambridge.

Ślęczka Ś. (1999), Feminizm. Ideologie $i$ koncepcje wspótczesnego feminizmu, Wydawnictwo "Książnica", Katowice. 
Tickner J. A. (1997a), You just Don't Understand: Troubled Engagements between Feminists and IR Theorists, "International Studies Quarterly", vol. 41, no. 4.

Tickner J. A. (1997b), Re-visioning Security, in: International Relations Theory Today, eds. K. Booth, S. Smith, Polity Press Cambridge.

True J. (1996), Feminism, in: Theories of International Relations, S. Burchill, A. Linklater (et al.), Macmillan Press Ltd, New York.

Verba S. (1961), Assumptions of Rationality and Non-Rationality in Models of the International System, in: International Politics and Foreign Policy: Reader in Research and Theory, ed. J. N. Rosenau, The Free Press of Glencoe, New York.

Walt S. M. (1991), The Renaissance of Security Studies, "International Studies Quarterly", vol. 35, no. 2 .

Wesley J. K. (2006), Considering the Context of Women's Violence: Gender Lived Experiences and Cumulative Victimisation, "Feminist Criminology", vol. 1, no. 4.

Wibben A. T. R. (2011), Feminist Security Studies: A Narrative Approach, Routledge, London-New York.

Yuval-Davis N. (1997), Gender and Nation, Sage, London.

Yuval-Davis N.(1999), What is 'Transversal Politics'?, "Soundings”, Issue 12.

Zięba A. (2016), Pteć terroryzmu - wprowadzenie do zagadnienia, Kwartalnik Naukowy OAP UW "e-Politikon", no. 20.

\section{Podejście feministyczne w studiach nad bezpieczeństwem}

\section{Streszczenie}

Zasadniczym celem artykułu jest przedstawienie problemów związanych ze stosowaniem podejścia feministycznego w badaniach nad bezpieczeństwem. Punkt wyjścia stanowią kwestie związane z podstawowymi terminami w obrębie zróżnicowanej wewnętrznie teorii feministycznej i ich zastosowania w obszarze nauk o polityce. Podjęto również próbę określenia celów wybranych badań feministycznych, które mogą być wykorzystane w analizie problemów z zakresu bezpieczeństwa wewnętrznego i międzynarodowego. Główną tezą artykułu jest stwierdzenie, że w badaniach nad bezpieczeństwem dominują przypisane płci stereotypy i znaczenia wpisujące się w tzw. męskie spojrzenie.

Słowa kluczowe: feminizm, płeć, bezpieczeństwo, badania nad bezpieczeństwem, nauki o polityce 
